\title{
Phylogenetic evidence for a new species of Barbus in the Danube River basin ${ }^{\text {is }}$
}

\author{
László Antal ${ }^{\mathrm{a}, *}$, Brigitta László ${ }^{\mathrm{b}}$, Petr Kotlík ${ }^{\mathrm{c}}$, Attila Mozsár ${ }^{\mathrm{a}, \mathrm{d}}$, István Czeglédi ${ }^{\mathrm{a}, \mathrm{d}}$, Miklós Oldal ${ }^{\mathrm{e}}$, \\ Gábor Kemenesi ${ }^{\mathrm{e}}$, Ferenc Jakab ${ }^{\mathrm{e}}$, Sándor Alex Nagy ${ }^{\mathrm{a}}$ \\ ${ }^{a}$ Department of Hydrobiology, Faculty of Science and Technology, University of Debrecen, Debrecen, Hungary \\ ${ }^{\mathrm{b}}$ Department of Medical Microbiology, University of Debrecen, Debrecen, Hungary \\ ${ }^{c}$ Laboratory of Molecular Ecology, Institute of Animal Physiology and Genetics, The Czech Academy of Sciences, Liběchov, Czech Republic \\ ${ }^{\mathrm{d}}$ Balaton Limnological Institute, MTA Centre for Ecological Research, Tihany, Hungary

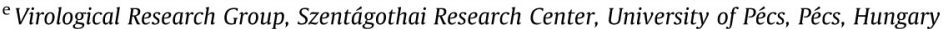

\section{A R T I C L E I N F O}

Article history:

Received 30 September 2015

Revised 19 November 2015

Accepted 30 November 2015

Available online $\mathrm{xxxx}$

\section{Keywords:}

Cyt $b$

ATPase 6/8

Act-2

Barbus biharicus

Biharian barbel

Cyprinidae

\begin{abstract}
A B S T R A C T
Three species of small-sized rheophilic Barbus fishes are endemic to and widely distributed throughout the mountain regions in the Danube River basin. In Hungary, barbels referred to as B. petenyi occur in streams in the foothills of the Carpathians near the borders with Slovakia, Ukraine and Romania. However, up to now, no genetic investigations were carried out on rheophilic barbels in this region. This study aims to clarify the taxonomic identity and distribution of the rheophilic barbels in the Hungarian plain based on molecular and morphological analyses. Two mitochondrial genes (cytochrome $b$, ATPase 6/8) and one nuclear gene (beta-actin intron 2) were sequenced and several morphometric and meristic characters were recorded. Phylogenetic and morphological analyses revealed that there are four genetically distinct lineages among the rheophilic barbels in the Carpathian Basin. The results demonstrated that NorthHungarian Barbus populations belong to B. carpathicus and that B. petenyi presumably does not occur in Hungary. As expected, $B$. balcanicus was only recorded in samples from the Balkans analyzed for reference. A distinct species, new to science, was discovered to be present in Sebes-Körös River (Crişul Repede) in eastern Hungary and western Romania and is formally described here as B. biharicus Antal, László, Kotlík - sp. nov.
\end{abstract}

(c) 2015 Elsevier Inc. All rights reserved.

\section{Introduction}

Petenyi's barbel (Barbus petenyi Heckel, 1852) is a small-sized rheophilic cyprinid species endemic to mountain regions of the Carpathian Basin (Kotlík et al., 2002; Bănărescu and Bogutskaya, 2003). The species was originally described from Transylvania in the present day Romania and was named after János Salamon Petényi, an eminent Hungarian zoologist (Bănărescu and Bogutskaya, 2003). Since the original description the taxonomic status of the species was controversial, with some authors considering it a subspecies of B. meridionalis Risso, 1827, or of B. peloponnesius Valenciennes, 1842 (Bănărescu, 1964; Karaman, 1971; Doadrio, 1990). Despite superficial morphological similarity of barbels from the

\footnotetext{
This paper was edited by the Associate Editor G. Orti.

* Corresponding author at: Department of Hydrobiology, University of Debrecen, P.O. Box 57, 4010 Debrecen, Hungary. Fax: +36 52 512900/23622.

E-mail address: antal.laszlo@science.unideb.hu (L. Antal).
}

different parts of the Danube River basin, separate evolutionary lineages were described within $B$. petenyi based on the high genetic divergence of mitochondrial DNA (mtDNA) sequences (Tsigenopoulos and Berrebi, 2000; Machordom and Doadrio, 2001a; Kotlík and Berrebi, 2002). Later on, Kotlík et al. (2002) formally described two new species from the Danube River basin, distinct from $B$. petenyi, which they named B. carpathicus Kotlík, Tsigenopoulos, Ráb and Berrebi, 2002, and B. balcanicus Kotlík, Tsigenopoulos, Ráb and Berrebi, 2002. Further phylogenetic analyses of nuclear and mitochondrial genes confirmed the presence of the three different species, which most likely diverged from each other in the Miocene (Marková et al., 2010; Gante, 2011; Berrebi et al., 2013; Konopiński et al., 2013; Buonerba et al., 2015). The Petenyi's barbel inhabits the Eastern and Southern Carpathians and the Stara Planina Mountains, the Carpathian barbel B. carpathicus occurs in the Western and Eastern Carpathians, and the large spot barbel $B$. balcanicus lives in the Dinaric and Western Stara Planina Mountains (Kotlík et al., 2002; Kottelat and Freyhof, 2007) (Fig. 1). 


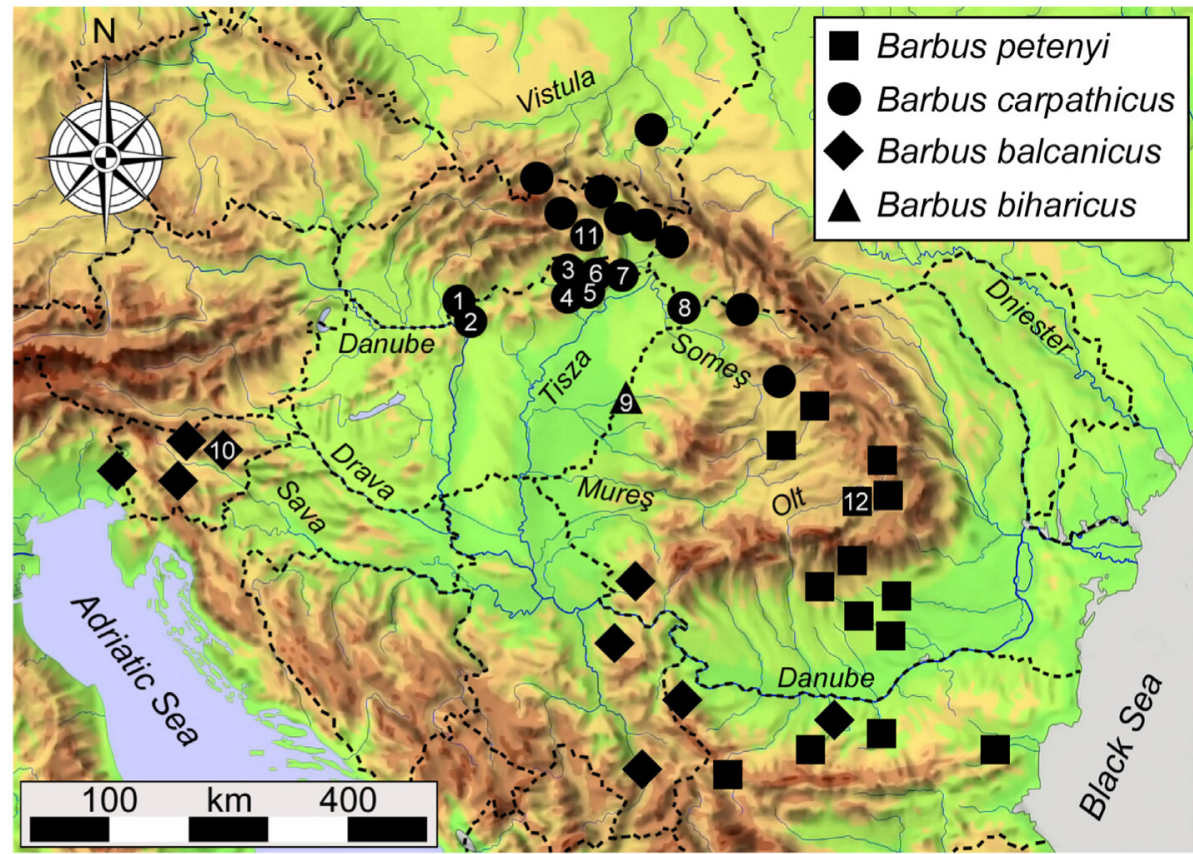

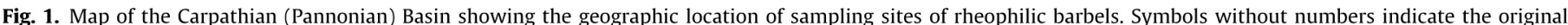

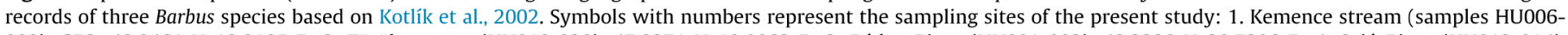

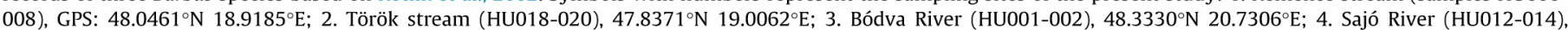

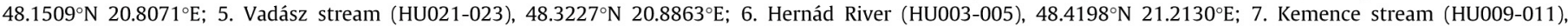

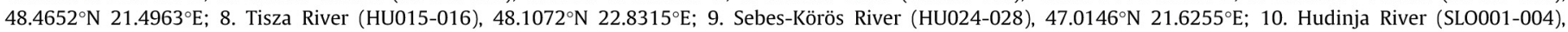
$46.2323^{\circ} \mathrm{N} 15.2778^{\circ} \mathrm{E} ; 11$. Torysa River (SK001-004), $48.9775^{\circ} \mathrm{N} 21.2539{ }^{\circ} \mathrm{E} ; 12$. Aita stream (RO001-004), $45.9838^{\circ} \mathrm{N} 25.6509^{\circ} \mathrm{E}$.

Due to their preference for mountain habitats, the rheophilic barbels are largely absent from the Hungarian (Pannonian) plain (Fig. 1). In Hungary, barbels referred to as $B$. petenyi occur in streams in the foothills of the Carpathians near the borders with Slovakia, Ukraine and Romania (Halasi-Kovács and Harka, 2012; Fig. 1). Due to the limited distribution in the country, B. petenyi is listed as strictly protected species in Hungary. However, up until now, no genetic investigations were carried out on rheophilic barbels in Hungary and their taxonomic status is therefore an open question. This study aims to clarify the taxonomic identity and distribution of the rheophilic barbels from the Hungarian plain based on molecular and morphological analyses.

\section{Materials and methods}

\subsection{Sampling}

Altogether, 28 individuals provisionally identified as B. petenyi were collected from nine geographical locations in Hungary, from all regions where the species was assumed to occur. Altogether 12 individuals of $B$. petenyi, B. carpathicus and $B$. balcanicus were collected as references from their habitats in Romania, Slovakia and Slovenia, respectively (Fig. 1). Samplings were carried out using electric sampling equipment (HansGrassl, Germany) in Hungary and hand nets in the other countries, between 2010 and 2012. Some individuals and the tissues samples were stored in $96 \%$ ethanol at $-20^{\circ} \mathrm{C}$ until DNA extraction. The collection and storage of the samples were approved by the National Inspectorate for Environment, Nature and Water, Hungary (permission number: 14/4620-3/2010.).

In 2015, additional 27 individuals of the suspected new species were collected from Sebes-Körös River (Crişul Repede) near Bratca, Romania $\left(46.9279^{\circ} \mathrm{N} 22.5934^{\circ} \mathrm{E}\right)$, for the morphometric and meristic examination.

\subsection{Molecular methods}

DNA was extracted with the DNeasy Blood and Tissue Kit (Qiagen, Germany) from tissue samples. Two mitochondrial genes and one nuclear gene were analyzed by polymerase chain reaction (PCR) with high fidelity AccuTaq ${ }^{\mathrm{TM}}$ DNA polymerase (SigmaAldrich, USA). Partial sequence of mitochondrial cytochrome $b$ (Cyt b) gene (598 bp) was amplified with primers L15267 (5'AAT GACTTGAAGAACCACCGT3') and H15891 (5'GTTTGATCCCGTTTCGT GTA3') designed by Briolay et al. (1998). The same Cyt $b$ fragment was used in previous studies (Tsigenopoulos and Berrebi, 2000; Kotlík and Berrebi, 2002; Tsigenopoulos et al., 2002), which allowed direct comparison with published data. The complete mitochondrial ATPase 6 and 8 genes ( $842 \mathrm{bp}$ ) were amplified with primers ATP8.2 (5'AAAGCRTYRGCCTTTTAAGC3') and C03.2 (5'GTT AGTGGTCAKGGGCTTGGRTC3') designed by Machordom and Doadrio (2001b). The second intron of the nuclear-encoded betaactin (Act-2) gene (496 bp) was amplified with primers Act18U21 (5'GCTCCAGAAAAACCTATAAGT3') and Act554L21 (5'CTCACTGAA GCTCCTCTTAAC3 ${ }^{\prime}$ ) described by Marková et al. (2010). Species from the genus Barbus are evolutionarily tetraploid, so that the primers were designed to selectively amplify a single paralogous copy of Act-2 (Marková et al., 2010). Briefly, the two paralogs (corresponding to the two ancestral diploid chromosome sets) were separated by electrophoresis based on the length difference between them, gel-purified and sequenced, and specific primers were designed to match regions differing in sequence, allowing selective amplification and sequencing of only the longer paralog in different species (Marková et al., 2010). The use of locus-specific primers is essential because it allows distinguishing allelic variation segregating at a single locus from variation between paralogous gene duplicates (Marková et al., 2010; Gante et al., 2011). The average uncorrected distance between the Act-2 paralogs (12.0\%) largely exceeds average levels within the paralogs $(1.6 \%$ and $1.1 \%$; 
Marková et al., 2010), allowing easy verification of the paralog specificity of the obtained sequences (e.g. Yang et al., 2015).

Amplified PCR products were purified using the QIAquick Gel Extraction Kit (Qiagen) after agarose gel electrophoresis. Direct cycle sequencing was carried out with the BigDye ${ }^{\circledR}$ Terminator v3.1 Cycle Sequencing Kit (Thermo Fisher Scientific, USA). The amplicons were bidirectionally sequenced on an ABI PRISM ${ }^{\circledR} 310$ Genetic Analyzer (Thermo Fisher Scientific) automated sequencer.

\subsection{Genetic data analysis}

Sequences were checked and aligned using the BioEdit version 7.2.5. software (Hall, 1999) and multiple alignments were manu- ally adjusted using the GeneDoc version 2.7 software (Nicholas et al., 1997). The new sequences were aligned with published homologous sequences (phased haplotypes in case of Act-2; Marková et al., 2010) for B. petenyi, B. carpathicus and B. balcanicus as well as for a few outgroup species (Zardoya and Doadrio, 1999; Tsigenopoulos and Berrebi, 2000; Machordom and Doadrio, 2001a; Kotlík and Berrebi, 2002; Tsigenopoulos et al., 2002; Marková et al., 2010; Levin et al., 2012; Konopiński et al., 2013; Buonerba et al., 2015; for GenBank accession numbers see Fig. 2). Sequences obtained in this study were deposited in GenBank under accession numbers KT733654 to KT733670.

Phylogenetic relationships among the sequences were reconstructed using the maximum likelihood optimality criterion. The
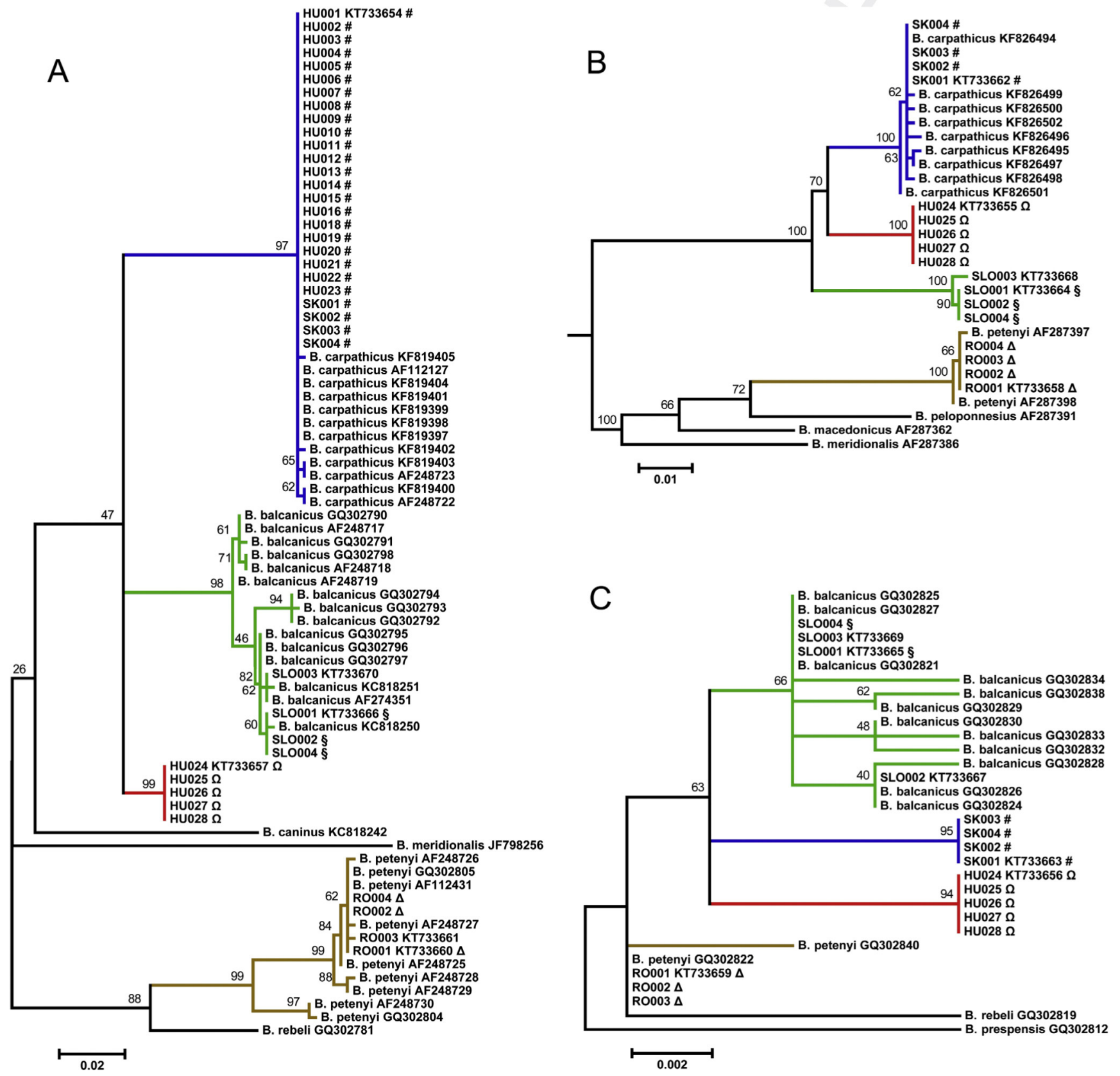

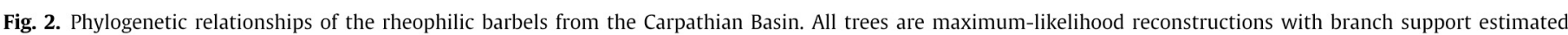
based on 1000 bootstrap replicates. (A) Cytochrome $b$ gene (TN93+G model). (B) ATPase $6 / 8$ gene (TN93+I). (C) Beta-actin gene intron 2 (T92). Previously published sequences are labelled with the species name and GenBank accession number. New sequences are labelled with the number of the individual sequenced. GenBank accession number is given for those individuals whose sequence was deposited in GenBank, with individuals carrying identical sequences indicated by symbols. Note that in (C) SLO003 differs from SLO001 by a single heterozygous site. Color coding: brown - B. petenyi, blue - B. carpathicus, green - B. balcanicus, red - B. biharicus. (For interpretation of the references to color in this figure legend, the reader is referred to the web version of this article.) 
TN93+G model of sequence evolution (Tamura and Nei, 1993; where $G$ stands for the gamma-distributed rates across sites) was determined to be the appropriate model for the Cyt $b$ dataset according to the Bayesian information criterion used as a measure of goodness of fit of different models to the data (Posada and Buckley, 2004; Tamura et al., 2011). A TN93+I model (where I is the proportion of invariable sites) was identified as the best-fit model for the ATPase 6/8 data set and a T92 model (Tamura 92) for the Act-2 dataset. Maximum-likelihood phylogenetic analyses were performed using the NNI (nearest neighbor interchanges) and SPR (subtree pruning and regrafting) tree search algorithms. Branch support for the phylogenetic partitioning in the trees was quantified by bootstrap analysis with 1000 random replicates (Felsenstein, 1985). The calculations were performed with both the MEGA6 (Tamura et al., 2013) and PhyML software (Guindon et al., 2010). Model-corrected pairwise genetic distances between species were calculated with MEGA6.

\subsection{Morphological data analysis}

Morphological analysis was performed to reveal any morphological differences between the Barbus species. The morphological characters (altogether 27) were scored based on Kotlik et al. (2002) and Žutinić et al. (2014). In the case of B. petenyi, B. carpathicus and B. balcanicus the dataset of Kotlík et al. (2002) was used.

In order to eliminate the effect of size, the morphometric data were standardized according to Elliott et al. (1995). Canonical Variance Analysis (CVA) was performed on the entire standardized dataset $(N=85)$ to test the interspecific differences with STATISTICA 12.0 software (StatSoft, 2013). Subsequently, Spearman rank correlation analysis were used to quantify the importance of each morphological feature (i.e., which are primarily responsible for the separation). In the cases of morphometric characters which proved to be significant additional ANOVA post-hoc (Tukey HSD) test were used to determine differences between species.

\section{Results and discussion}

\subsection{DNA sequence analysis} bp sequences of Cyt $b$ and five haplotypes among the 17 aligned 842 -bp sequences of ATPase 6/8. Six unique sequences were identified among the 16 aligned 496-bp sequences of Act-2. All new Act-2 sequences were homozygous over the entire length, except for two B. balcanicus (SLO002 and SLO003), which were both heterozygous at the same site, with an additional site being heterozygous in SLO002. The sequences of SLO002 and SLO003
There were six different haplotypes among the 39 aligned 546- were analyzed as heterozygous with the heterozygous sites encoded with IUPAC symbols.

Phylogenetic relationships were reconstructed independently for each gene, with the analyses using MEGA6 (Fig. 2) yielding virtually identical results to those obtained with PhyML (not shown). The analysis combining new Cyt $b$ data with B. petenyi, B. carpathicus and $B$. balcanicus sequences from GenBank unambiguously recovered the three clades known from the previous studies to correspond to these species (Fig. 2A). The majority of samples collected in different Hungarian populations were genetically closely related to B. carpathicus (HU001 to HU023) except for five fish (HU024 to HU028) collected in Sebes-Körös River (Crişul Repede), which formed a distinct clade (Fig. 2A). All of the new $B$. carpathicus sequences carried the same haplotype while two haplotypes were identified in the new samples of each $B$. balcanicus and $B$. petenyi, and another single haplotype was shared by all individuals in the new clade (Fig. $2 \mathrm{~A}$ ).

To test whether the Cyt $b$ differentiation of barbels from SebesKörös River is reflected also by divergence at other genes, a subset of samples were selected for analyses of additional mtDNA and nuclear loci. The mitochondrial ATPase 6/8 and the nuclear Act-2 genes were amplified and sequenced in samples of the three species and in the samples from Sebes-Körös River. In all analyses, the samples of the three species and the Crişul Repede samples segregated into four distinct clades (Fig. 2B and C). In the case of B. balcanicus, two haplotypes of ATPase 6/8 and three haplotypes of Act-2 (two of them heterozygous; see above) were identified, while in the other species only one haplotype was found for each gene. The present study is the first to report the sequences of ATPase 6/8 genes for B. balcanicus and of Act-2 for B. carpathicus.

From these results it can be concluded that the rheophilic barbels from North-Hungary belong to B. carpathicus and are closely related to B. carpathicus from Slovakia. However, the results suggest that $B$. petenyi does not occur in Hungary. Instead, the phylogenetic analyses suggest that the rheophilic barbels from SebesKörös River in eastern Hungary belong to a distinct genetic lineage with a differentiation as great as that among other species (Table 1), thus representing a new, fourth species in the Carpathian Basin.

\subsection{Morphological analysis}

According to the result of CVA, the three known species and the new species show remarkable morphological differences based on the 27 recorded characters (Table 2). The first canonical axis of CVA explained $71.6 \%$ of the total variance (Fig. 3 ; Eigenvalue $=5.58$; Canonical $R=0.92$; Wilks' $\lambda=0.03$; Chi $^{2}$ test $\left.P<0.0001\right)$. The second axis accounted for $17.9 \%$ of the total variance (Eigenvalue $=1.39$;
Table 1

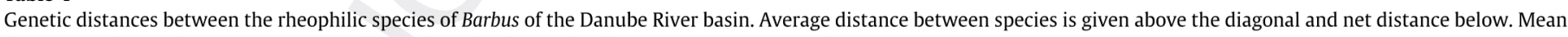
distance within each species is given in bold along the diagonal. All estimates are expressed as percentages.

\begin{tabular}{|c|c|c|c|c|c|}
\hline Gene & Species & B. petenyi & B. carpathicus & B. balcanicus & B. biharicus \\
\hline \multirow[t]{4}{*}{ Cyt $b$} & B. petenyi & 1.4 & 10.7 & 10.9 & 9.2 \\
\hline & B. carpathicus & 10.0 & 0.1 & 6.0 & 5.2 \\
\hline & B. balcanicus & 9.7 & 5.5 & 0.9 & 4.3 \\
\hline & B. biharicus & 8.5 & 5.2 & 3.8 & 0.0 \\
\hline \multirow[t]{4}{*}{ ATPase $6 / 8$} & B. petenyi & 0.1 & 11.6 & 11.1 & 11.3 \\
\hline & B. carpathicus & 10.2 & 0.2 & 4.7 & 3.3 \\
\hline & B. balcanicus & 9.9 & 4.3 & 0.2 & 4.5 \\
\hline & B. biharicus & 10.1 & 3.1 & 4.2 & 0.0 \\
\hline \multirow[t]{4}{*}{ Act-2 } & B. petenyi & 0.2 & 0.9 & 0.7 & 0.9 \\
\hline & B. carpathicus & 0.8 & 0.0 & 1.0 & 1.2 \\
\hline & B. balcanicus & 0.4 & 0.9 & 0.3 & 1.0 \\
\hline & B. biharicus & 0.8 & 1.2 & 0.9 & 0.0 \\
\hline
\end{tabular}


Table 2

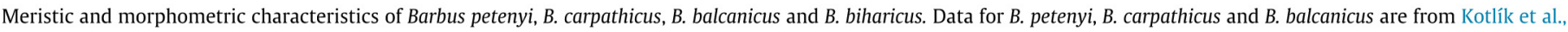
2002.

\begin{tabular}{|c|c|c|c|c|c|c|c|c|}
\hline & \multicolumn{2}{|c|}{ Barbus petenyi } & \multicolumn{2}{|c|}{ Barbus carpathicus } & \multicolumn{2}{|c|}{ Barbus balcanicus } & \multicolumn{2}{|c|}{ Barbus biharicus } \\
\hline $\begin{array}{l}\text { Meristic characters } \\
\text { Rays in dorsal fin } \\
\text { Rays in anal fin } \\
\text { Scale counts }\end{array}$ & $\begin{array}{l}\mathrm{III} / 7-8 \\
\mathrm{I}-\mathrm{II} / 4-5 \\
528-11 / 8\end{array}$ & 1059 & $\begin{array}{l}\mathrm{II}-\mathrm{III} / 7-8 \\
\mathrm{I}-\mathrm{II} / 4-5 \\
518-11 / 8\end{array}$ & 964 & $\begin{array}{l}\text { II-III/7-8 } \\
\text { I-III/4-5 } \\
518-11 / 8\end{array}$ & 1061 & $\begin{array}{l}\text { II-III/7-8 } \\
\text { I-II } / 4-5 \\
519-11 / 8-1\end{array}$ & 56 \\
\hline Morphometric characters & $\begin{array}{l}\text { Neotype } \\
\text { NMW- } \\
94602\end{array}$ & $\begin{array}{l}N=13 \\
\text { Mean } \pm \text { SD } \\
\text { Range }\end{array}$ & $\begin{array}{l}\text { Holotype } \\
\text { NMW- } \\
94604\end{array}$ & $\begin{array}{l}N=20 \\
\text { Mean } \pm \text { SD } \\
\text { Range }\end{array}$ & $\begin{array}{l}\text { Holotype } \\
\text { NMW- } \\
94609\end{array}$ & $\begin{array}{l}N=18 \\
\text { Mean } \pm \text { SD } \\
\text { Range }\end{array}$ & $\begin{array}{l}\text { Holotype } \\
\text { HNHM-ICH } \\
2015.51 .1 .\end{array}$ & $\begin{array}{l}N=28 \\
\text { Mean } \pm \text { SD } \\
\text { Range }\end{array}$ \\
\hline $\mathrm{SL}(\mathrm{mm})$ & 135.0 & $\begin{array}{l}122.2 \pm 11.4 \\
110.0-143.0\end{array}$ & 110.0 & $\begin{array}{l}151.4 \pm 23.2 \\
110.0-186.0\end{array}$ & 130.0 & $\begin{array}{l}136.8 \pm 16.3 \\
114.0-174.0\end{array}$ & 79.3 & $\begin{array}{l}90.9 \pm 15.7 \\
55.2-115.3\end{array}$ \\
\hline \multicolumn{9}{|l|}{ In percent of $S L$} \\
\hline Total length & 119.3 & $\begin{array}{l}117.3 \pm 3.5 \\
107.1-120.2\end{array}$ & 117.3 & $\begin{array}{l}115.9 \pm 2.2 \\
111.1-120.3\end{array}$ & 113.1 & $\begin{array}{l}115.5 \pm 1.8 \\
111.5-118.5\end{array}$ & 119.4 & $\begin{array}{l}117.4 \pm 1.2 \\
115.1-120.7\end{array}$ \\
\hline Head length & 24.8 & $\begin{array}{l}23.4 \pm 1.1 \\
20.8-24.8\end{array}$ & 24.8 & $\begin{array}{l}24.6 \pm 0.6 \\
23.1-25.6\end{array}$ & 24.6 & $\begin{array}{l}24.2 \pm 1.1 \\
22.0-26.1\end{array}$ & 23.7 & $\begin{array}{l}23.5 \pm 1.2 \\
21.3-25.9\end{array}$ \\
\hline Maximum body depth & 21.6 & $\begin{array}{l}21.2 \pm 1.4 \\
19.1-23.1\end{array}$ & 21.7 & $\begin{array}{l}20.8 \pm 1.0 \\
18.6-22.6\end{array}$ & 26.1 & $\begin{array}{l}21.5 \pm 1.6 \\
18.8-26.1\end{array}$ & 22.0 & $\begin{array}{l}20.9 \pm 1.2 \\
18.7-23.4\end{array}$ \\
\hline Predorsal distance & 51.9 & $\begin{array}{l}48.7 \pm 2.5 \\
43.7-51.9\end{array}$ & 48.8 & $\begin{array}{l}49.7 \pm 1.2 \\
46.3-52.2\end{array}$ & 50.2 & $\begin{array}{l}49.6 \pm 2.2 \\
45.5-54.2\end{array}$ & 51.8 & $\begin{array}{l}51.5 \pm 1.5 \\
48.4-54.3\end{array}$ \\
\hline Preanal distance & 69.9 & $\begin{array}{l}69.7 \pm 2.5 \\
64.4-74.1\end{array}$ & 71.5 & $\begin{array}{l}73.8 \pm 1.6 \\
71.5-77.4\end{array}$ & 72.0 & $\begin{array}{l}73.0 \pm 2.6 \\
67.6-77.7\end{array}$ & 76.2 & $\begin{array}{l}77.5 \pm 1.3 \\
74.9-80.8\end{array}$ \\
\hline Preventral distance & 53.6 & $\begin{array}{l}50.7 \pm 2.1 \\
45.9-53.6\end{array}$ & 53.1 & $\begin{array}{l}53.2 \pm 1.2 \\
50.7-55.3\end{array}$ & 51.2 & $\begin{array}{l}52.4 \pm 1.8 \\
50.2-56.6\end{array}$ & 56.6 & $\begin{array}{l}56.7 \pm 1.4 \\
54.1-59.2\end{array}$ \\
\hline Distance between pectoral and ventral fin bases & 30.4 & $\begin{array}{l}29.5 \pm 1.5 \\
26.6-32.8\end{array}$ & 29.5 & $\begin{array}{l}29.0 \pm 1.3 \\
26.2-31.7\end{array}$ & 29.3 & $\begin{array}{l}29.6 \pm 1.0 \\
28.0-32.5\end{array}$ & 34.9 & $\begin{array}{l}33.8 \pm 2.1 \\
26.8-36.7\end{array}$ \\
\hline Distance between pectoral and anal fin bases & 48.9 & $\begin{array}{l}49.2 \pm 2.6 \\
44.5-53.3\end{array}$ & 49.5 & $\begin{array}{l}49.9 \pm 1.7 \\
46.6-54.5\end{array}$ & 50.2 & $\begin{array}{l}51.3 \pm 1.4 \\
49.5-54.4\end{array}$ & 54.0 & $\begin{array}{l}54.6 \pm 2.2 \\
48.7-58.4\end{array}$ \\
\hline Length of caudal paduncle & 18.1 & $\begin{array}{l}17.9 \pm 1.1 \\
15.8-19.2\end{array}$ & 19.5 & $\begin{array}{l}18.3 \pm 1.1 \\
17.0-21.4\end{array}$ & 18.9 & $\begin{array}{l}18.3 \pm 1.4 \\
15.9-21.2\end{array}$ & 17.6 & $\begin{array}{l}16.7 \pm 1.1 \\
13.2-18.9\end{array}$ \\
\hline Minimum body depth & 9.3 & $\begin{array}{l}9.6 \pm 0.4 \\
9.0-10.4\end{array}$ & 9.5 & $\begin{array}{l}9.0 \pm 0.6 \\
7.5-9.8\end{array}$ & 10.5 & $\begin{array}{l}9.5 \pm 0.8 \\
7.9-10.9\end{array}$ & 9.5 & $\begin{array}{l}9.2 \pm 0.3 \\
8.5-9.8\end{array}$ \\
\hline Depth of caudal paduncle & 12.9 & $\begin{array}{l}11.5 \pm 0.7 \\
10.5-12.9\end{array}$ & 11.7 & $\begin{array}{l}10.8 \pm 1.0 \\
9.0-13.6\end{array}$ & 12.0 & $\begin{array}{l}10.5 \pm 0.7 \\
9.3-12.0\end{array}$ & 11.3 & $\begin{array}{l}11.0 \pm 0.5 \\
10.3-12.3\end{array}$ \\
\hline Length of dorsal fin base & 12.2 & $\begin{array}{l}12.1 \pm 0.9 \\
10.4-13.8\end{array}$ & 12.1 & $\begin{array}{l}13.0 \pm 0.9 \\
10.8-14.6\end{array}$ & 12.1 & $\begin{array}{l}11.8 \pm 0.7 \\
10.2-12.8\end{array}$ & 12.5 & $\begin{array}{l}12.5 \pm 0.5 \\
11.5-14.2\end{array}$ \\
\hline Depth of anal fin & 18.3 & $\begin{array}{l}18.8 \pm 2.4 \\
15.3-23.3\end{array}$ & 17.4 & $\begin{array}{l}20.3 \pm 2.6 \\
15.9-24.1\end{array}$ & 20.2 & $\begin{array}{l}22.0 \pm 1.7 \\
19.7-24.9\end{array}$ & 15.4 & $\begin{array}{l}15.0 \pm 1.7 \\
12.7-19.3\end{array}$ \\
\hline Length of anal fin base & 6.4 & $\begin{array}{l}6.7 \pm 0.8 \\
4.9-7.9\end{array}$ & 7.5 & $\begin{array}{l}7.7 \pm 0.5 \\
6.9-8.8\end{array}$ & 7.2 & $\begin{array}{l}7.6 \pm 0.9 \\
6.1-8.9\end{array}$ & 6.8 & $\begin{array}{l}6.7 \pm 0.5 \\
5.3-8.3\end{array}$ \\
\hline Length of ventral fin & 15.4 & $\begin{array}{l}14.4 \pm 0.8 \\
13.1-15.4\end{array}$ & 14.9 & $\begin{array}{l}13.9 \pm 0.8 \\
12.6-15.9\end{array}$ & 13.7 & $\begin{array}{l}13.9 \pm 0.8 \\
12.0-15.5\end{array}$ & 15.5 & $\begin{array}{l}14.8 \pm 0.7 \\
13.2-15.9\end{array}$ \\
\hline Length of pectoral fin & 18.5 & $\begin{array}{l}18.2 \pm 0.8 \\
16.3-19.3\end{array}$ & 17.6 & $\begin{array}{l}17.3 \pm 0.9 \\
16.0-19.1\end{array}$ & 16.6 & $\begin{array}{l}16.9 \pm 1.4 \\
13.0-19.2\end{array}$ & 21.2 & $\begin{array}{l}20.3 \pm 1.1 \\
16.1-21.6\end{array}$ \\
\hline Length of upper caudal lobe & 23.7 & $\begin{array}{l}22.1 \pm 2.0 \\
18.4-24.7\end{array}$ & 23.2 & $\begin{array}{l}21.0 \pm 1.0 \\
19.4-23.2\end{array}$ & & $\begin{array}{l}20.0 \pm 1.7 \\
16.9-23.1\end{array}$ & 22.3 & $\begin{array}{l}21.3 \pm 0.9 \\
19.3-23.1\end{array}$ \\
\hline Length of middle caudal part & 10.2 & $\begin{array}{l}9.0 \pm 0.9 \\
7.1-10.3\end{array}$ & 10.3 & $\begin{array}{l}8.4 \pm 0.8 \\
6.9-10.3\end{array}$ & 8.4 & $\begin{array}{l}8.2 \pm 0.9 \\
6.4-10.2\end{array}$ & 9.3 & $\begin{array}{l}9.0 \pm 0.7 \\
7.9-11.1\end{array}$ \\
\hline Length of lower caudal lobe & 23.5 & $\begin{array}{l}22.0 \pm 2.0 \\
17.9-24.4\end{array}$ & 23.2 & $\begin{array}{l}19.4 \pm 1.6 \\
16.5-23.2\end{array}$ & 18.7 & $\begin{array}{l}18.8 \pm 1.5 \\
16.8-23.1\end{array}$ & 24.0 & $\begin{array}{l}21.1 \pm 1.9 \\
12.9-24.0\end{array}$ \\
\hline Body width & $13.8 \bigcirc$ & $\begin{array}{l}12.7 \pm 1.4 \\
10.9-15.4\end{array}$ & 14.3 & $\begin{array}{l}12.5 \pm 1.2 \\
9.9-15.0\end{array}$ & 14.4 & $\begin{array}{l}14.2 \pm 2.1 \\
11.1-17.5\end{array}$ & 15.8 & $\begin{array}{l}15.0 \pm 0.9 \\
11.8-16.6\end{array}$ \\
\hline Head width & 14.8 & $\begin{array}{l}14.5 \pm 1.3 \\
12.6-17.7\end{array}$ & 14.0 & $\begin{array}{l}13.9 \pm 0.7 \\
12.5-14.9\end{array}$ & 15.2 & $\begin{array}{l}14.4 \pm 1.7 \\
11.9-16.9\end{array}$ & 14.3 & $\begin{array}{l}14.2 \pm 0.5 \\
13.0-15.3\end{array}$ \\
\hline Preorbital distance & 11.0 & $\begin{array}{l}9.9 \pm 0.7 \\
8.8-11.0\end{array}$ & 11.1 & $\begin{array}{l}11.4 \pm 0.5 \\
10.3-12.4\end{array}$ & 9.4 & $\begin{array}{l}10.5 \pm 0.9 \\
8.5-11.8\end{array}$ & 8.6 & $\begin{array}{l}8.8 \pm 0.3 \\
8.3-9.3\end{array}$ \\
\hline Postorbital distance & 11.0 & $\begin{array}{l}10.6 \pm 0.5 \\
9.6-11.4\end{array}$ & 9.9 & $\begin{array}{l}10.3 \pm 0.4 \\
9.8-11.3\end{array}$ & 10.7 & $\begin{array}{l}10.5 \pm 0.6 \\
9.4-11.7\end{array}$ & 10.2 & $\begin{array}{l}9.9 \pm 0.7 \\
8.7-11.4\end{array}$ \\
\hline Horizontal eye diameter & 4.9 & $\begin{array}{l}4.1 \pm 0.5 \\
3.2-4.9\end{array}$ & 4.7 & $\begin{array}{l}3.8 \pm 0.4 \\
3.1-4.7\end{array}$ & 4.3 & $\begin{array}{l}3.9 \pm 0.4 \\
3.1-4.6\end{array}$ & 4.9 & $\begin{array}{l}4.9 \pm 0.5 \\
3.9-5.9\end{array}$ \\
\hline Interorbital distance & 6.4 & $\begin{array}{l}6.7 \pm 0.5 \\
6.0-7.5\end{array}$ & 7.0 & $\begin{array}{l}7.2 \pm 0.5 \\
6.4-8.3\end{array}$ & 7.2 & $\begin{array}{l}7.2 \pm 0.5 \\
6.1-8.0\end{array}$ & 9.2 & $\begin{array}{l}8.4 \pm 0.5 \\
7.2-9.5\end{array}$ \\
\hline Head depth & 15.2 & $\begin{array}{l}14.1 \pm 0.7 \\
13.3-15.4\end{array}$ & 14.7 & $\begin{array}{l}14.2 \pm 0.5 \\
13.5-14.7\end{array}$ & 16.6 & $\begin{array}{l}15.4 \pm 0.7 \\
14.2-16.8\end{array}$ & 17.4 & $\begin{array}{l}16.4 \pm 0.9 \\
15.0-17.7\end{array}$ \\
\hline
\end{tabular}

Canonical $R=0.76$; Wilks' $\lambda=0.23$; $\mathrm{Chi}^{2}$ test $P<0.0001$ ). The correlation analyses confirmed that the head depth $(r=-0.79)$, the interorbital distance $(r=-0.78)$, and the preanal distance $(r=-0.78)$ played the most important roles in the morphological separation of the species. These morphological characters showed strong negative correlation with the first axis and were the highest
$(P<0.0001)$ in the new Barbus species, with the exception of the head depth which did not differ significantly $(P=0.2465)$ between the new species and $B$. balcanicus. The preorbital distance $(r=0.58)$, and the length of upper $(r=0.56)$ and lower $(r=0.48)$ caudal lobe positively correlated with the first axis. The preorbital distance was the lowest $(P<0.0001)$ in the new species. 


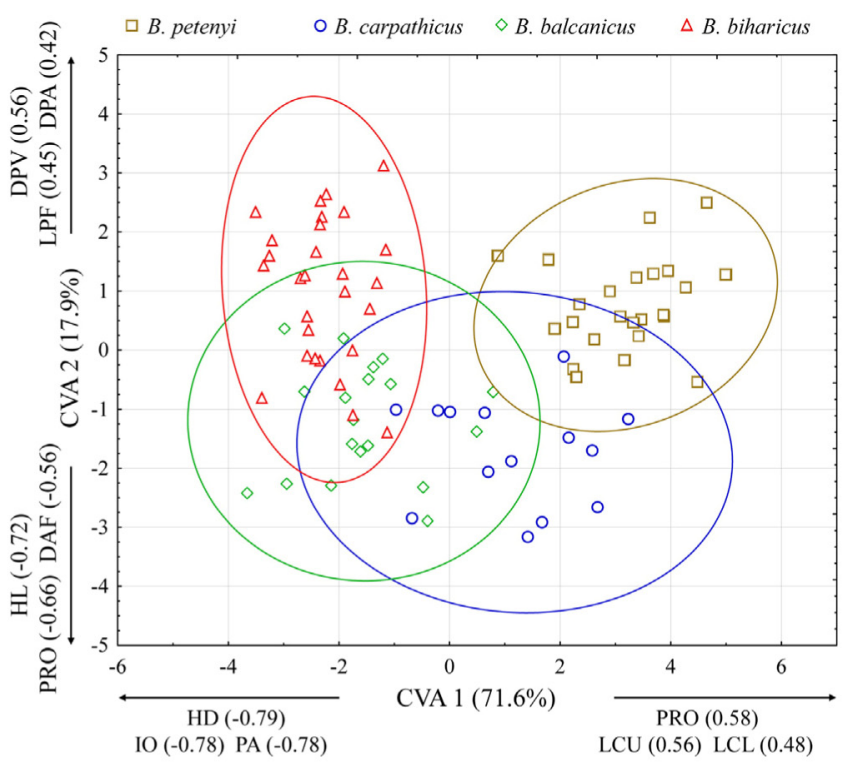

Fig. 3. Discriminant analysis for comparison of the morphology of Barbus species. The isodensity circles contain the $95 \%$ of the specimens classified into a certain group. Abbreviations: HL: head length; PRO: preorbital distance; DAF: depth of anal fin; DPV: distance between pectoral and ventral fin bases; LPF: length of pectoral fin; DPA: distance between pectoral and anal fin bases; HD: head depth; IO: interorbital distance; PA: preanal distance; LCU: length of upper caudal lobe; LCL: length of lower caudal lobe.

In contrast to the morphometric characters, meristic characters did not show significant differences between the four species. Numbers of rays in the dorsal and anal fins as well as scale counts (numbers of pored scales along lateral lines and numbers of scale rows above and below lateral lines) were nearly the same for all species (Table 2).

\subsection{Historical biogeography}

The isostatic uplift of the Apuseni Mountains (Munții Apuseni) in the Miocene (Late Badenian-Early Sarmatian) might play an important role in the isolation of the Barbus species (ThamóBozsó et al., 2002). The Apuseni Mountains form an important barrier to gene flow between the species because there is an insurmountable geographical barrier between the main streams of the area (Szamos/Someş River, Maros/Mureş River, Körös/Criş Rivers). The separation of the main streams therefore likely contributed to the genetic and morphological differentiation of the new species from $B$. carpathicus and $B$. petenyi in that it prevented effective gene flow via hybridization, which is known to occur between other Barbus species (Berrebi et al., 2013; Gante et al., 2015).

The congruence between the molecular phylogenetic and the morphometric analyses provides evidence that barbels from Sebes-Körös River in eastern Hungary and western Romania are a species new to science. A formal description of the new species follows.

\subsection{Barbus biharicus Antal, László, Kotlík - sp. nov.}

\subsubsection{Holotype}

The holotype of B. biharicus (Fig. 4) was deposited in the Hungarian Natural History Museum, Ichthyological Collection, under lot HNHM-ICH-2015.51.1; adult male; $79.3 \mathrm{~mm}$ SL; Romania: Danube River basin: Sebes-Körös River (Crişul Repede), tributary of Tisza River, at Bratca, $46.9279^{\circ} \mathrm{N} 22.5934^{\circ} \mathrm{E}$; collected by I. C. Telcean and L. Antal, 24 June 2015.

\subsubsection{Paratype}

The paratype of $B$. biharicus was deposited in the Hungarian Natural History Museum, Ichthyological Collection under lot HNHM-ICH-2015.48.1. (formerly HU026); adult male; $82.5 \mathrm{~mm}$ SL; Hungary: Danube River basin: Sebes-Körös River (Crişul Repede), tributary of Tisza River, at Körösszakál, $47.0146^{\circ} \mathrm{N}$ $21.6255^{\circ} \mathrm{E}$; collected by L. Antal, A. Mozsár \& I. Czeglédi, 30 September 2010.

\subsubsection{Diagnosis}

Barbus biharicus is distinguished from the other species by three diagnostic nucleotide substitutions in the studied 546-bp region of Cyt $b$ [position $12 \mathrm{~A}$ (adenine) $\rightarrow \mathrm{G}$ (guanine); position $186 \mathrm{C}$ (cytosine) $\rightarrow \mathrm{T}$ (thymine); position $435 \mathrm{~A} \rightarrow \mathrm{G}$; GenBank accession number KT733657], by 8 diagnostic nucleotide substitutions in the studied 842-bp region of ATPase 6/8 [position $14 \mathrm{~A} \rightarrow \mathrm{G}$; position $60 \mathrm{C} \rightarrow \mathrm{T}$; position $423 \mathrm{C} \rightarrow \mathrm{T}$; position $483 \mathrm{C} \rightarrow \mathrm{T}$; position 551 $\mathrm{A} \rightarrow \mathrm{G}$; position $692 \mathrm{C} \rightarrow \mathrm{G}$; position $707 \mathrm{~A} \rightarrow \mathrm{G}$; position 728 $A \rightarrow G$; GenBank accession number KT733655] and by three diagnostic nucleotide substitution in the studied 496-bp region of Act-2 [position $157 \mathrm{~T} \rightarrow \mathrm{A}$; position $300 \mathrm{G} \rightarrow \mathrm{C}$; position $373 \mathrm{~T} \rightarrow$ C; GenBank accession number KT733656]. Although there is overlap in most meristic and morphometric characters (Table 2), B. biharicus has significantly larger interorbital and preanal distance than $B$. balcanicus, B. carpathicus and B. petenyi, and significantly deeper head than $B$. carpathicus and $B$. petenyi. It also has a ten-

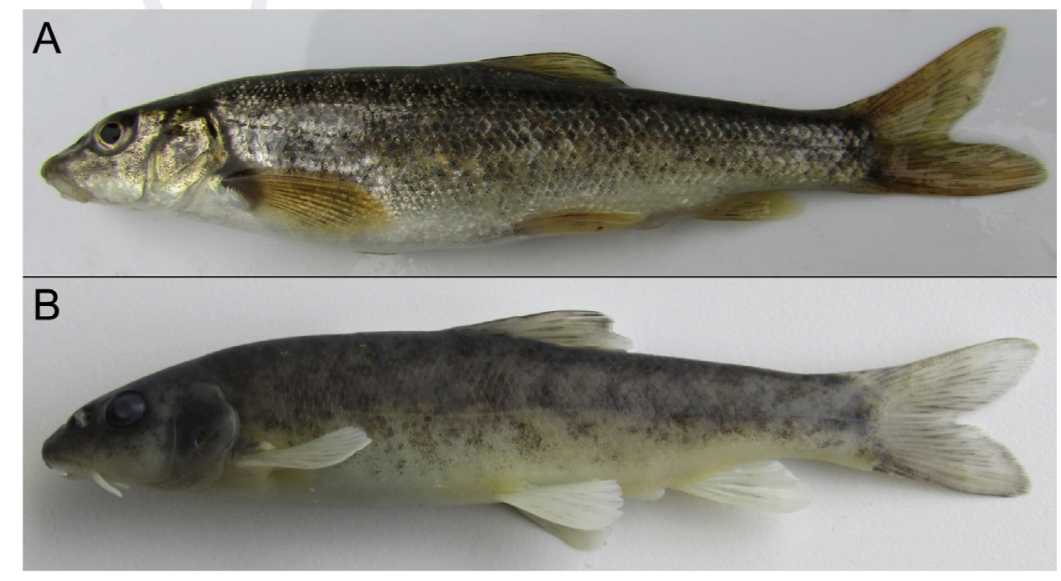

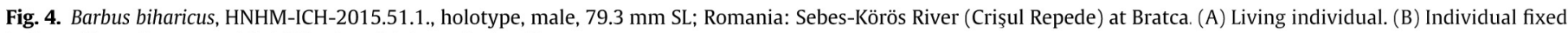
in formalin and preserved in $70 \%$ ethanol (photo: L. Antal). 
dency to have shorter, rounded snout, slightly longer pectoral fins, but slightly shorter anal fin than the other three species. Barbus biharicus has small dark spots on dorsal region of body and flanks and, to a lesser extent, head, and dark pigments on the fins occasionally form dark spots (the other species have heavy dark spots, which typically are arranged into rows on dorsal and caudal fins).

\subsubsection{Description}

General body shape and appearance are shown in Fig. 4 and the meristic and morphometric characters are given in Table 2 . There are 2 (in 11 individuals) or 3 (in 16 individuals) unbranched rays and 7 (1) or 8 (26) branched rays in the dorsal fin, which has a slightly concave outer margin. There are 1 (2) or 2 (25) unbranched rays and 4 (14) or 5 (13) branched rays in the anal fin, which when depressed can reach to (male) or beyond (female) the middle of caudal peduncle. There are 51-56 (mean 53.7, SD 1.3) pored scales along the lateral line; 9 (9), 10 (16) or 11 (2) scale rows above the lateral line; 8 (3), 9 (22) or 10 (2) scale rows below the lateral line. Coloration of living specimens is dark greyish-brown on dorsal region of body and head, yellowish brown on flanks, yellowish white on ventral region, and yellowish ${ }^{1}$ on fins (Fig. 4).

\subsubsection{Sexual dimorphism}

Anal fin of female is markedly longer than that of male.

\subsubsection{Distribution}

Barbus biharicus is presently known only from Hungarian and Romanian sections of Sebes-Körös River (Crişul Repede), a tributary of Tisza River, which is a tributary of the Danube River. The species presumably lives also in the Fekete-Körös River (Crişul Negru) and Fehér-Körös River (Crişul Alb).

\subsubsection{Etymology}

Named after the Bihar Counties (there are counties with this name in both Romania and Hungary), where the species is almost exclusively distributed. Suggested common name: Biharian barbel.

\section{Acknowledgments}

We are thankful to all the scientists who participated in the sample collection, namely Meta Povž (SLO), Ján Koščo (SK), Géza Péter, Ilie Cătălin Telcean, István Sas-Kovács, Alfred-Stefan CicortLucaciu (RO), and Béla Halasi-Kovács (HU). We would like to express our thanks to Judit Vörös, senior curator of the Hungarian Natural History Museum, Ichthyological Collection (HNHM-ICH), for her administrative work. We would like to thank Professor Zoltán Varga and Eszter Csoma for valuable personal communication. The work was supported by the TÁMOP-4.2.2/B-10/1-20100024 project. The project is co-financed by the European Union and the European Social Fund. L.A. and B.L. were supported by the European Union and the State of Hungary, co-financed by the European Social Fund in the framework of TÁMOP 4.2.4. A/2-111-2012-0001 'National Excellence Program'. P.K. received the institutional support RVO:67985904.

\section{References}

Bănărescu, P.M., 1964. Fauna Republicii Populare Romine [Fauna of the People's Republic of Romania, vol. 13]. Pisces - Osteichthyes. Acad. Rep. Pop. Romine, Bucuresti (in Romanian).

Bănărescu, P.M., Bogutskaya, N.G. (Eds.), 2003. The Freshwater Fishes of Europe Cyprinidae 2. Pt. II: Barbus, vol. 5/II. AULA-Verlag, Wiebelsheim.

Berrebi, P. Chenuil, A. Kotlík, P. Machordom, A., Tsigenopoulos, C.S, 2013. Disentangling the evolutionary history of the genus Barbus sensu lato, a

${ }^{1}$ For interpretation of color in Fig. 4, the reader is referred to the web version of this article. twenty years adventure. In: Alves, J. (Ed.), Professor Carlos Almaça (19342010) - Estado da Arte em Áreas Cientificas que Desenvolveu. Museu Nacional de Historia Natural e da Ciencia, Lisboa, pp. 29-55.

Briolay, J., Galtier, N., Brito, R.M., Bouvet, Y., 1998. Molecular phylogeny of Cyprinidae inferred from cytochrome $b$ DNA sequences. Mol. Phylogenet. Evol. 9, 100-108.

Buonerba, L., Zaccara, S., Delmastro, G.B., Lorenzoni, M., Salzburger, W., Gante, H.F., 2015. Intrinsic and extrinsic factors act at different spatial and temporal scales to shape population structure, distribution and speciation in Italian Barbus (Osteichthyes: Cyprinidae). Mol. Phylogenet. Evol. 89, 115-129.

Doadrio, I., 1990. Phylogenetic relationships and classification of western palaearctic species of the genus Barbus (Osteichthyes, Cyprinidae). Aquat. Living Resour. 3, 265-282.

Elliott, N.G., Haskard, K., Koslow, J.A., 1995. Morphometric analysis of orange roughly (Hoplostethus atlanticus) off the continental slope of southern Australia. J. Fish Biol. 46, 202-220.

Felsenstein, J., 1985. Confidence limits on phylogenies: an approach using the bootstrap. Evolution 39, 783-791.

Gante, H.F., 2011. Diversification of circum-mediterranean barbels. In: Grillo, 0. Venora, G. (Eds.), Changing Diversity in Changing Environment. InTech, Rijeka, Croacia, pp. 283-298.

Gante, H.F., Alves, M.J., Dowling, T.E., 2011. Paralog-specific primers for the amplification of nuclear loci in tetraploid barbels (Barbus: cypriniformes). J. Hered. 102, 617-621.

Gante, H.F., Doadrio, I., Alves, M.J., Dowling, T.E., 2015. Semi-permeable species boundaries in Iberian barbels (Barbus and Luciobarbus, Cyprinidae). BMC Evol. Biol. 15, 111.

Guindon, S., Dufayard, J.-F., Lefort, V., Anisimova, M., Hordijk, W., Gascuel, O., 2010. New algorithms and methods to estimate maximum-likelihood phylogenies: assessing the performance of PhyML 3.0. Syst. Biol. 59, 307321.

Halasi-Kovács, B., Harka, Á., 2012. How many fish species are existing in Hungary? Zoogeographic and taxonomic review and evaluation of the Hungarian fishfauna. Pisc. Hung. 6, 5-24 (in Hungarian).

Hall, T.A., 1999. BioEdit: a user-friendly biological sequence alignment editor and analysis program for Windows 95/98/NT. Nucl. Acids Symp. Ser. 41, 95-98.

Karaman, S.M., 1971. Süsswasserfische der Türkei. 8. Teil: Revision der Barben Europas, Vorderasien und Nordafrikas. Mitt. Hamburg. Zool. Mus. Inst. 67, 175254

Konopiński, M.K., Amirowicz, A., Kotlík, P., Kukuła, K., Bylak, A., Pekarik, L., Šediva, A., 2013. Back from the Brink: the Holocene History of the Carpathian Barbel Barbus carpathicus. PLoS One 8, e82464.

Kotlík, P., Berrebi, P., 2002. Genetic subdivision and biogeography of the Danubian rheophilic barb Barbus petenyi inferred from phylogenetic analysis of mitochondrial DNA variation. Mol, Phylogenet. Evol. 24, 10-18.

Kotlík, P. Tsigenopoulos, C.S., Ráb, P., Berrebi, P., 2002. Two new Barbus species from the Danube River basin, with redescription of B. petenyi (Teleostei: Cyprinidae) Folia Zool. 51, 227-240.

Kottelat, M., Freyhof, J., 2007. Handbook of European Freshwater Fishes. Publications Kottelat, Cornol, Switzerland.

Levin, B.A., Freyhof, J., Lajbner, Z., Perea, S., Abdoli, A., Gaffaroglu, M., Ozulug, M., Rubenyan, H.R., Salnikov, V.B., Doadrio, I., 2012. Phylogenetic relationships of the algae scraping cyprinid genus Capoeta (Teleostei: Cyprinidae). Mol. Phylogenet. Evol, 62, 542-549.

Machordom, A., Doadrio, I., 2001a. Evolutionary history and speciation modes in the cyprinid genus Barbus. Proc. R. Soc. Lond. Biol. 268, 1297-1306.

Machordom, A., Doadrio, I., 2001b. Evidence of a cenozoic betic-kabilian connection based on freshwater fish phylogeography (Luciobarbus, Cyprinidae). Mol. Phylogenet. Evol. 18, 252-263.

Marková, S., Šanda, R., Crivelli, A., Shumka, S., Wilson, I.F., Vukić, J., Berrebi, P., Kotlik, P. 2010. Nuclear and mitochondrial DNA sequence data reveal the evolutionary history of Barbus (Cyprinidae) in the ancient lake systems of the Balkans. Mol. Phylogenet. Evol. 55, 488-500.

Nicholas, K.B., Nicholas Jr. H.B., Deerfield, D.W., 1997. GeneDoc: analysis and visualization of genetic variation. EMBnet News 4, 14.

Posada, D., Buckley, T.R., 2004. Model selection and model averaging in phylogenetics: advantages of akaike information criterion and bayesian approaches over likelihood ratio tests. Syst. Biol. 53, 793-808.

StatSoft, Inc., 2013. STATISTICA (Data Analysis Software System), Version 12.0. <wWw.statsoft.com>.

Tamura, K., 1992. Estimation of the number of nucleotide substitutions when there are strong transition-transversion and G+C-content biases. Mol. Biol. Evol. 9, 678-687.

Tamura, K., Nei, M., 1993. Estimation of the number of nucleotide substitutions in the control region of mitochondrial DNA in humans and chimpanzees. Mol. Biol. Evol. 10, 512-526.

Tamura, K., Peterson, D., Peterson, N., Stecher, G., Nei, M., Kumar, S., 2011. MEGA5: molecular evolutionary genetics analysis using maximum likelihood, evolutionary distance, and maximum parsimony methods. Mol. Biol. Evol. 28, 2731-2739.

Tamura, K., Stecher, G., Peterson, D., Filipski, A., Kumar, S., 2013. MEGA6: molecular evolutionary genetics analysis version 6.0. Mol. Biol. Evol. 30, $2725-2729$

Thamó-Bozsó, E., Kercsmár, Zs., Nádor, A., 2002. Tectonic control on changes in sediment supply: quaternary alluvial systems, Körös sub-basin, SE
385

386

387 
Yang, L., Sado, T., Hirt, M.V., Pasco-Viel, E., Arunachalam, M., Li, J., Wang, X., Freyhof, J., Saitoh, K., Simons, A.M., Miya, M., He, S., Mayden, R.L., 2015. Phylogeny and polyploidy: resolving the classification of cyprinine fishes (Teleostei: Cypriniformes). Mol. Phylogenet. Evol. 85, 97-116.

In: Jones, S.J., Frostick, L.E. (Eds.), Sediment Flux to Ba pp. 37-53.

Tsigenopoulos, C.S., Berrebi, P., 2000. Molecular phylogeny of North Mediterranean freshwater barbs (genus Barbus: Cyprinidae) inferred from cytochrome $b$ sequences: biogeographic and systematic implications. Mol. Phylogenet. Evol. $14,165-179$.

Tsigenopoulos, C.S., Kotlik, P., Berrebi, P., 2002. Biogeography and pattern of gene flow among Barbus species (Teleostei: Cyprinidae) inhabiting the Italian Peninsula and neighbouring Adriatic drainages as revealed by allozyme and mitochondrial sequence data. Biol. J. Linn. Soc. Lond. 75, 83-99.

Zardoya, R., Doadrio, I., 1999. Molecular evidence on the evolutionary and biogeographical patterns of European cyprinids. J. Mol. Evol. 49, 227237.

Žutinić, P., Jelić, D., Jelić, M., Buj, I., 2014. A contribution to understanding the ecology of the large spot barbel - sexual dimorphism, growth and population structure of Barbus balcanicus (Actinopterygii; Cyprinidae) in Central Croatia. North-West. J. Zool. 10, 158-166. 